Original Article

\title{
Effects of neutrophil extracellular traps during human respiratory syncytial virus infection in vitro
}

\author{
Efeitos das redes extracelulares dos neutrófilos durante a infecção in vitro pelo vírus \\ sincicial respiratório
}

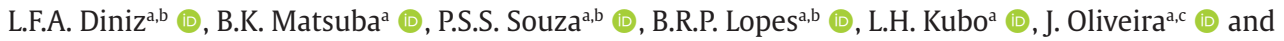 \\ K.A. Toledo ${ }^{\mathrm{a}, \mathrm{b}}$ (D)* \\ aUniversidade Estadual Paulista - UNESP, Departmento de Ciências Biológicas, Assis, SP, Brasil \\ bUniversidade Estadual Paulista - UNESP, Programa de Pós-Graduação em Microbiologia, São José do Rio Preto, SP, Brasil \\ 'Universidade Estadual Paulista de Londrina - UEL, Programa de Pós-Graduação em Matemática Aplicada e Computacional - PGMAC, Londrina, \\ PR, Brasil
}

\begin{abstract}
The human respiratory syncytial virus (hRSV) is the most common cause of severe lower respiratory tract diseases in young children worldwide, leading to a high number of hospitalizations and significant expenditures for health systems. Neutrophils are massively recruited to the lung tissue of patients with acute respiratory diseases. At the infection site, they release neutrophil extracellular traps (NETs) that can capture and/or inactivate different types of microorganisms, including viruses. Evidence has shown that the accumulation of NETs results in direct cytotoxic effects on endothelial and epithelial cells. Neutrophils stimulated by the hRSV-F protein generate NETs that are able to capture hRSV particles, thus reducing their transmission. However, the massive production of NETs obstructs the airways and increases disease severity. Therefore, further knowledge about the effects of NETs during hRSV infections is essential for the development of new specific and effective treatments. This study evaluated the effects of NETs on the previous or posterior contact with hRSV-infected Hep-2 cells. Hep-2 cells were infected with different hRSV multiplicity of infection (MOI 0.5 or 1.0), either before or after incubation with NETs $(0.5-16 \mu \mathrm{g} / \mathrm{mL})$. Infected and untreated cells showed decreased cellular viability and intense staining with trypan blue, which was accompanied by the formation of many large syncytia. Previous contact between NETs and cells did not result in a protective effect. Cells in monolayers showed a reduced number and area of syncytia, but cell death was similar in infected and non-treated cells. The addition of NETs to infected tissues maintained a similar virus-induced cell death rate and an increased syncytial area, indicating cytotoxic and deleterious damages. Our results corroborate previously reported findings that NETs contribute to the immunopathology developed by patients infected with hRSV.
\end{abstract}

Keywords: viral infection, innate immunity, human respiratory syncytial virus, neutrophils, NETs.

\begin{abstract}
Resumo
O vírus sincicial respiratório humano (hRSV) é a causa mais comum de doenças graves do trato respiratório inferior em crianças pequenas em todo o mundo, resultando em grande número de hospitalizações e gastos significativos para os sistemas de saúde. Neutrófilos são recrutados em massa para o tecido pulmonar de pacientes com doenças respiratórias agudas. No local da infecção, eles liberam armadilhas extracelulares de neutrófilos (NETs) que podem capturar e/ou inativar diferentes tipos de microrganismos, incluindo vírus. Evidências demonstraram que o acúmulo de NETs resulta em efeitos citotóxicos diretos nas células endoteliais e epiteliais. Os neutrófilos estimulados pela proteína F do vírus sincicial respiratório (hRSV-F) geram NETs que são capazes de capturar partículas virais, reduzindo assim sua transmissão. No entanto, a produção maciça de NETs obstrui as vias aéreas e aumenta a gravidade da doença. Assim, um maior conhecimento sobre os efeitos das NETs durante as infecções por hRSV é essencial para o desenvolvimento de novos tratamentos específicos e eficazes. Este estudo avaliou os efeitos das NETs no contato prévio ou posterior à infecção de células Hep-2 com hRSV. As células Hep-2 foram infectadas com diferentes quantidades de hRSV (multiplicidade de infecção ou MOI 0,5 ou 1,0), antes ou após a incubação com NETs $(0,5-16 \mu \mathrm{g} / \mathrm{mL})$. Células infectadas e não tratadas mostraram redução da viabilidade celular e intensa coloração com azul de tripano, que foi acompanhada pela formação de sincícios numerosos e grandes. O contato prévio entre as NETs e as células não resultou em efeito protetor. As células em monocamadas mostraram um número e área de sincícios reduzidos, mas a morte celular foi semelhante àquela apresentada por células infectadas e não tratadas. A adição de NETs aos tecidos infectados manteve taxa de morte celular e formação de sincícios semelhantes
\end{abstract}

*e-mail: karina.toledo@unesp.br

Received: April 7, 2021 - Accepted: June 17, 2021

This is an Open Access article distributed under the terms of the Creative Commons Attribution License, which permits unrestricted use, distribution, and reproduction in any medium, provided the original work is properly cited. 
àqueles induzidos pelo vírus em células não tratadas, indicando danos citotóxicos e deletérios. Nossos resultados corroboram achados relatados anteriormente de que as NETs contribuem para a imunopatologia desenvolvida por pacientes infectados com hRSV.

Palavras-chave: infecção viral, imunidade inata, vírus sincicial respiratório humano, neutrófilos, NETs.

\section{Introduction}

The human respiratory syncytial virus (hRSV) was first described in 1957 as the agent responsible for bronchiolitis in children, especially those under five years of age (Hall, 2001). hRSV infections affect people of all ages, but mostly children and the elderly. Co-infections with respiratory viruses, including hRSV, result in high mortality and morbidity (Bawage et al., 2013). To date, treatments for hRSV are only palliative and there is no vaccine available.

The inflammatory process induced by hRSV in the airways of infants with bronchiolitis is dominated by an intense influx of neutrophils (Everard et al., 1994; Smith et al., 2001). The F-protein, located on the hRSV surface, activates the release of neutrophil extracellular traps (NETs) from neutrophils in the infected tissue (Funchal et al., 2015). NETs were first described in 2004; their release is stimulated by several inflammatory mediators and pathogens (Brinkmann et al., 2004). These traps are composed of nuclear/mitochondrial DNA and proteins from the nucleus, cytoplasm, and cytoplasmic granules (Fuchs et al., 2007; Urban et al., 2009), and have a microbicidal and viricidal role (Jenne et al., 2013; Saitoh et al., 2012; Brinkmann et al., 2004). In vitro, NETs induce death in pulmonary epithelial cells and endothelial cell lines (Saffarzadeh et al., 2012), suggesting that they have a toxic effect on the alveolar-capillary barrier. In some chronic respiratory diseases, such as cystic fibrosis (CF), asthma, and chronic obstructive pulmonary disease (COPD), airway obstruction by a dense mass of DNA and protein-rich mucus is a pathological marker (Dubois et al., 2012; Manzenreiter et al., 2012; Papayannopoulos et al., 2011; Wright et al., 2016).

During hRSV infections, NETs trap hRSV particles, thereby limiting the spread of the virus (Cortjens et al., 2016). On the other hand, the dense mass of NETs found in the airways and lungs of children with severe hRSV infection impairs their respiratory capacity and contributes to the aggravation of the disease (Cortjens et al., 2016). Although several studies have proposed the adverse effects of neutrophil responses in hRSV infections (Stokes et al., 2011; Stokes et al., 2013; Stoppelenburg et al., 2014), whether the presence of NETs during hRSV infections is more beneficial or detrimental for the host has yet to be determined.

Studies on the microbicidal role of NETs in bacteria are common and continue to increase (Papayannopoulos, 2018). However, there is a lack of knowledge regarding the effects of NETs on viruses, and more research is necessary to elucidate the benefits or drawbacks of interactions between NETs and virus. Here, we evaluated the effects of NETs during the course of an hRSV infection in vitro. For this purpose, epithelial cells were pre- and post-treated with NETs and infected with hRSV. They were then evaluated for cell viability and the presence of syncytial formation, a morphologic characteristic of replicating hRSV.

\section{Material and Methods}

\subsection{Ethics statement}

The experimental procedures involving human blood were approved by the Local Ethics Committee on Human Research of the Faculdade de Ciências e Letras de Assis - FCL UNESP (42048315.5.0000.540), Assis, São Paulo state (SP), Brazil. Written informed consent, which was suggested and approved by the Committee, was obtained from each participant before beginning the investigation procedures.

\subsection{Cellular culture}

Hep-2 cells (oropharyngeal carcinoma) were purchased from the Bank of Cells of Rio de Janeiro (BCRJ, Rio de Janeiro, Brazil) and expanded in $75 \mathrm{~cm}^{2}$ culture flasks (Corning Glass Works, New York, NY, USA). They were grown in a humidified incubator at $37{ }^{\circ} \mathrm{C}$ and $5 \% \mathrm{CO}_{2}$ in DMEM-F12 medium (Sigma-Aldrich, Saint Louis, MO, USA) supplemented with $10 \%$ fetal bovine serum (FBS; Cultilab, Campinas, SP, Brazil), antibiotics, and antimycotics (Gibco, Life Technologies, Gaithersburg, MD, USA).

\subsection{Viral stock}

The hRSV long strain, provided by Prof. Dr. Eurico de Arruda Neto (Medical School of Ribeirão Preto, USP, Ribeirão Preto, SP, Brazil), was amplified in Hep-2 cells. Viral stocks were prepared in serum-free DMEM-F12 medium, and aliquots were subsequently frozen at $-80^{\circ} \mathrm{C}$ in DMEM supplemented with $10 \%$ trehalose (Gupta et al., 1996). The viral titer was established through a plaque assay, as previously described (McKimm-Breschkin, 2004), and confirmed using the TCID $_{50}$ method (Rasmussen et al., 2011).

\subsection{Isolation and stimulus of human neutrophils for NET production}

We collected $10 \mathrm{~mL}$ of peripheral blood from healthy volunteers, both female and male individuals ( $>18$ years old) were included and individuals using antiinflammatory drugs were excluded. The blood was placed it in BD Vacutainer ${ }^{\circledR}$ tubes (BD Biosciences, Franklin Lakes, NJ, USA) containing sodium citrate and was processed in a double density gradient (Histopaque 1119 and 1077, Sigma-Aldrich) according to the manufacturer's instructions. NETs were generated following the protocol described by Brinkmann et al. (2010), with modifications (Najmeh et al., 2015; Saffarzadeh et al., 2012). Briefly, the isolated neutrophils were diluted in serum-free RPMI 
medium supplemented with $25 \mathrm{nM}$ phorbol myristate acetate (PMA), and seeded in a 6 -well plate $\left(1.8 \times 10^{6}\right.$ cells $/$ well). The medium was discarded after incubation $(3 \mathrm{~h}$, $37{ }^{\circ} \mathrm{C}, 5 \% \mathrm{CO}_{2}$ ) and the NETs were collected by washing with serum-free RPMI and incubated in a water bath $\left(24 \mathrm{~h}\right.$ at $40^{\circ} \mathrm{C}$ ) (Souza et al., 2018). Next, samples were centrifuged $(800 \times \mathrm{g}, 5 \mathrm{~min})$ and the supernatant was stored at $-20{ }^{\circ} \mathrm{C}$ in a freezer. The DNA concentration of the samples was measured with a $\mathrm{Qubit}^{\circledR} 2.0$ Fluorometer using the PicoGreen dsDNA Assay Kit (Invitrogen, Inc., Grand Island, NY, USA).

\subsection{Evaluation of the anti-hRSV effect of NETs}

The anti-hRSV properties of human PMA-induced NETs were assayed for their pre- and post-treatment effects on hRSV-infected Hep-2 cells as described by Bettega et al. (2004). Cell viability was estimated using a colorimetric MTT [1-(4,5-Dimethylthiazol-2-yl)-3,5-Diphenylformazan thiazolyl blue formazan] assay and trypan blue dye incorporation assay. Multinucleated cells (syncytia) were identified and counted, and their areas were calculated as described below.

Pre-treatment assay: Confluent Hep-2 monolayers $\left(5 \times 10^{4}\right.$ cells/well $)$ were incubated with NETs $(0.5-16 \mu \mathrm{g} / \mathrm{mL})$ for $2 \mathrm{~h}$ at $37^{\circ} \mathrm{C}$ in a 96 -well plate. Next, the NET supernatant was replaced with a viral inoculum with different multiplicity of infection (MOI 0.5 or 1.0). Following infection $\left(2 \mathrm{~h}, 37^{\circ} \mathrm{C}\right)$, the viral suspension was replaced with serumfree DMEM-F12 medium. The cells were incubated for three days at $37{ }^{\circ} \mathrm{C}$ and $5 \% \mathrm{CO}_{2}$. Cellular control (CC, untreated and uninfected cells) and viral control (VC, untreated and infected cells) were included in the assay. Analyses were performed on the third day after infection.

Post-treatment assay: Confluent Hep-2 monolayers $\left(5 \times 10^{4}\right.$ cells/well $)$ were infected with viral inoculum (MOI 0.5 or 1.0 ) for $2 \mathrm{~h}$ at $37^{\circ} \mathrm{C}$ in a 96-well plate. The viral suspension was replaced with NETs $(0.5-16 \mu \mathrm{g} / \mathrm{mL})$ diluted in serum-free DMEM-F12 medium. Cells were incubated for three days at $37^{\circ} \mathrm{C}$ and $5 \% \mathrm{CO}_{2}$. $\mathrm{CC}$ and VC were also included in this assay. Analyses were performed on the third day after infection.

\subsection{Syncytium evaluation}

Three days after infection, cells were analyzed microscopically for the presence of syncytia. The number of syncytia was counted through microscopic observation using the well diameter as a parameter (from top to base). After counting, images from each well were captured using a camera attached to a Nikon eclipse TS 100 microscope (Nikon, Tokyo, Japan). These images were processed using an algorithm developed and carried out using the MATLAB ${ }^{\circledR}$ software (Pasieka et al., 2003; Matkowskyj et al., 2000; Larsen, 1998). In brief, the image files were segmented to isolate the syncytium from the background. A binary matrix was obtained in which the number zero (0) represented the background pixels, and the number one (1) represented syncytium pixels (object). The syncytial area was estimated by converting the pixels to $\mathrm{mm}^{2}$ using an area limit of $0.01 \mathrm{~mm}^{2}$.

\subsection{MTT assay (cellular viability)}

The protective effect of NETs against infected cells, pre- or post-treatment, was indirectly assessed using a colorimetric MTT assay following the manufacturer's recommendations (Sigma-Aldrich). This colorimetric assay evaluates the cell viability based on the ability of cells to reduce the MTT salt to formazan crystals using the succinic dehydrogenase enzyme. The metabolism of the salt is directly proportional to the metabolic rate, meaning that cellular viability can be calculated from the measured absorbance. Following treatment (3-day incubation), we replaced the culture medium with the MTT solution $(0.5 \mathrm{mg} / \mathrm{mL})$ and incubated the cells for $2 \mathrm{~h}$ at $37^{\circ} \mathrm{C}$. Subsequently, the MTT solution was replaced with $50 \mu \mathrm{L} /$ well dimethylsulfoxide (DMSO, Sigma-Aldrich) to dissolve the formazan crystals. Absorbance at $560 \mathrm{~nm}$ was recorded using a Multiskan ${ }^{\mathrm{TM}}$ FC Microplate Photometer (Thermo Fisher Scientific, Waltham, MA, USA) and the values were converted to the percentage of viable cells. Cellular control (untreated and uninfected cells) and viral control (untreated and infected cells) represented 100\% and $0 \%$ cellular viability, respectively. The cellular viability percentage was obtained for each tested condition using a protection equation (Equation 1 ) as follows:

$$
\text { Cellular viability }(\%)=\frac{O D_{T-} O D_{V C}}{O D_{C C-} O D_{V C}} * 100
$$

where:

$\mathrm{OD}$ is the optical density at $560 \mathrm{~nm}$;

ODT-OD $\mathrm{vc}_{\mathrm{vc}}$ is the optical density of the treatment - optical density of the viral control;

$\mathrm{OD}_{\mathrm{CC}}-\mathrm{OD}_{\mathrm{vc}}$ is the optical density of the cell control - optical density of the viral control.

\subsection{Trypan blue staining}

Cell viability was also evaluated based on trypan blue incorporation. At the end of each treatment, we administered a $0.4 \%$ trypan blue solution to each well for $30 \mathrm{~s}$ and then carefully washed it with phosphate buffered saline. Blue stains indicate regions of cell death, as evaluated using visual analysis.

\subsection{Statistical analysis}

All assays were repeated three or five times and were performed using triplicate samples. Experimental data were processed using Microsoft Excel (version 16.33) or GraphPad Prism 6 and evaluated using Wilcoxon test. A level of significance of $p \leq 0.05$ was used.

\section{Results}

\subsection{Effects of pre-treatment with NETs on the hRSV- infected Hep-2 cells}

Hep- 2 cells were incubated with different concentrations of NETs $(0.5-16 \mu \mathrm{g} / \mathrm{mL})$ for $2 \mathrm{~h}$ and then infected with the virus at different MOIs ( 0.5 or 1.0$)$. The following parameters 
were observed after infection: cell viability, the presence/ absence of syncytia, and the number and area of syncytia.

The results of the treatment with viral inoculum at a MOI of 0.5 demonstrated that previous contact of the cells with NETs did not result in total protection from hRSV infection, although it resulted in a reduction in the number and area of syncytia (Figure 1 ). We observed that only NET concentrations of 8 and $16 \mu \mathrm{g} / \mathrm{mL}$ showed trend to reducing number of syncytia, but that was not statistically significant compared with non-treated cells (Figure 1A, left). Meanwhile, the cells treated with NETs showed a decreasing syncytial area in a dose-dependent manner (Figure 1A, center). The area of the syncytium was smaller than the detection limit of the algorithm used in the calculation for NET concentrations of 8 and $16 \mu \mathrm{g} / \mathrm{mL}$. Cell viability was also evaluated (Figure $1 \mathrm{~A}$, right). Data from the MTT assay did not reveal any protective effects of NETs, as the viability of the treated cells was similar to that viral control (VC). These observations were complemented and corroborated by the trypan blue assay results (Figure $1 \mathrm{~B}$, bottom panel). Trypan blue is not a permeable dye; as such, the incorporation of trypan blue into cells occurs when there is cell membrane damage, resulting in dead cells being stained blue. Trypan blue staining revealed intense cell damage in all infected cells, both treated and non-treated (Figure 1B; bottom panel). The morphology of cells (Figure 1B, top panel) confirmed the presence of syncytia and elongated cells among the VC following infection. Infected cells that were treated with NETs showed an elongated morphology (at 2 and $4 \mu \mathrm{g} / \mathrm{mL}$ ) and detachment (at 8-16 $\mu \mathrm{g} / \mathrm{mL}$ ). Together, these results demonstrate that pre-treatment of hRSV-infected cells with NETs reduces the presence of cellular syncytia but does not protect the tissue from cell damage.

Treatment with the inoculum of higher MOI (1.0) showed similar results to those obtained using an inoculum with a MOI of 0.5 , with none of the tested NET concentrations inducing significant levels of protection (Figure 2). Prior contact with NETs ( 8 and $16 \mu \mathrm{g} / \mathrm{mL}$ ) resulted in an apparent decrease in the syncytium count (Figure 2A, left), and all NET concentrations resulted in a reduction in syncytium area (Figure 2A, center). Despite this reduction in syncytium number and area, cell viability remained low, as determined by the MTT assay. The cell viability of infected and treated cells was close to that of the VC (Figure $2 \mathrm{~A}$, on the right). The incorporation of trypan blue was intense in infected cells, treated with or without NETs (Figure 2B, bottom panel). Cell morphology analysis confirmed the presence of syncytia in infected cells (Figure 2B, top panel). The cells treated with NETs showed an elongated morphology $(2-8 \mu \mathrm{g} / \mathrm{mL})$ and detachment from the culture vessel $(16 \mu \mathrm{g} / \mathrm{mL})$. The results obtained with MOI 1.0 repeated the findings from the MOI 0.5 replicates, that prior contact with NETs did not protect the tissue from damage.
A Syncytium count

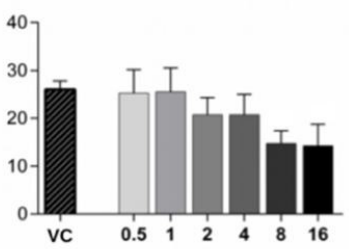

NET concentration $(\mu \mathrm{g} / \mathrm{mL})$
Syncytium size $\left(\mathrm{mm}^{2}\right)$

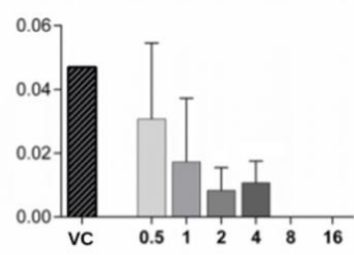

NET concentration $(\mu \mathrm{g} / \mathrm{mL})$
Cellular viability $(\%)$

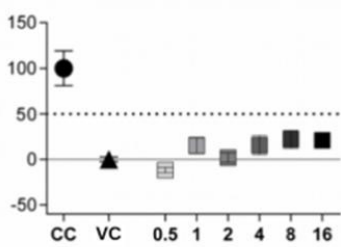

NET concentration $(\mu \mathrm{g} / \mathrm{mL})$

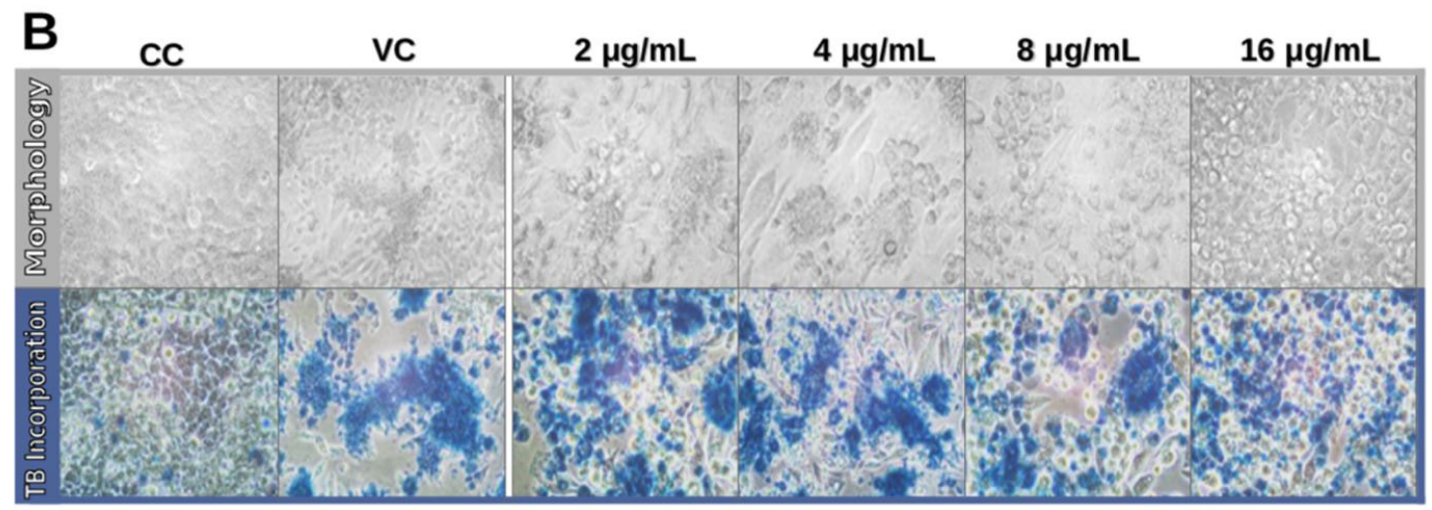

Figure 1. Effects of pre-treatment with NETs on hRSV-infected cells (MOI 0.5). Hep-2 cells were pre-treated with different concentrations of NETs $(0.5-16 \mu \mathrm{g} / \mathrm{mL}$ ) and infected with hRSV (MOI 0.5). On the third day of culture, cells were evaluated for (A) syncytium number and area and cellular viability via the MTT assay, and (B) morphology and cell viability through trypan blue incorporation (TB incorporation). Graphs and images are representative of three independent experiments performed in triplicate. They show the mean of obtained values \pm standard deviation. Human respiratory syncytial virus (hRSV); neutrophil extracellular traps (NETs) 


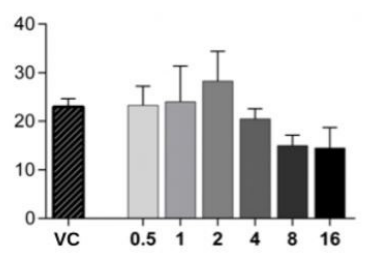

NET concentration $(\mu \mathrm{g} / \mathrm{mL})$

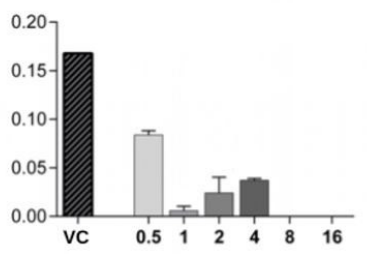

NET concentration $(\mu \mathrm{g} / \mathrm{mL})$

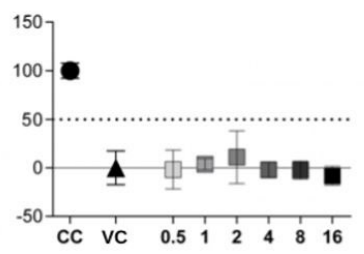

NET concentration $(\mu \mathrm{g} / \mathrm{mL})$

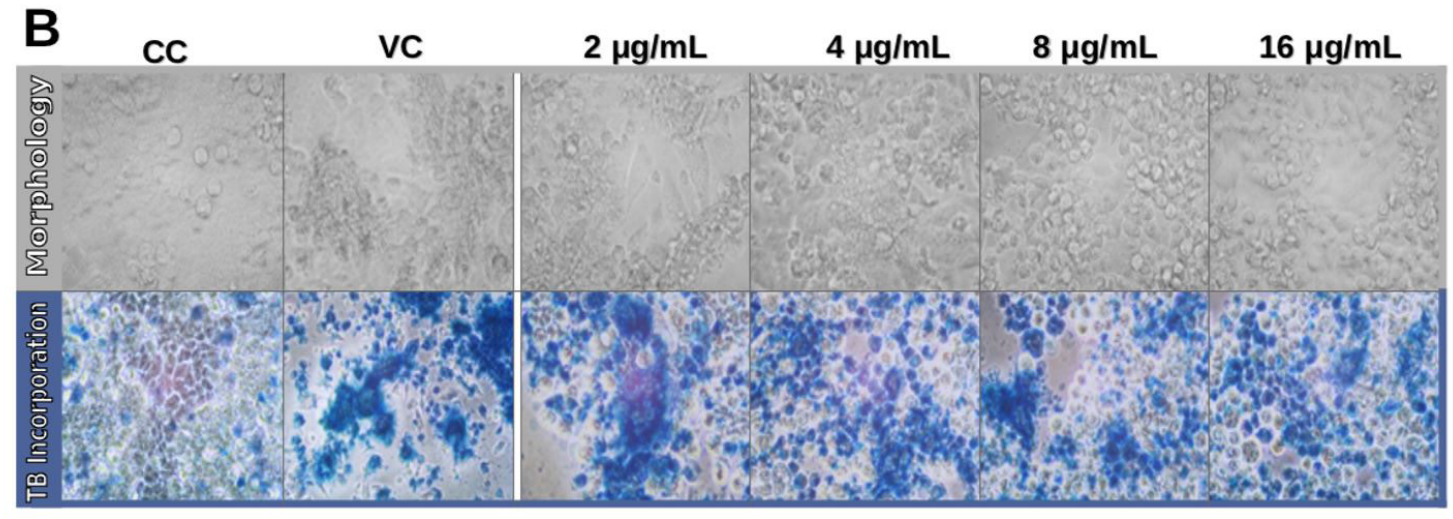

Figure 2. Effects of pre-treatment with NETs on hRSV-infected cells (MOI 1.0). Hep-2 cells were pre-treated with different concentrations of NETs $(0.5-16 \mu \mathrm{g} / \mathrm{mL})$ and infected with hRSV (MOI 1.0). On the third day of culture, cells were evaluated for (A) syncytium number and area and cellular viability via the MTT assay, and (B) cell morphology and viability through trypan blue incorporation (TB incorporation). Graphs and images are representative of three independent experiments performed in triplicate. They show the mean of obtained values \pm standard deviation. Human respiratory syncytial virus (hRSV); neutrophil extracellular traps (NETs)

\subsection{NET post-treatment effects on hRSV-Hep-2 infected cells}

Hep-2 cells were incubated with the virus at different MOIs ( 0.5 or 1.0 ) for $2 \mathrm{~h}$. After incubation, the cell monolayers were maintained for three days in the presence of different concentrations of NETs $(0.5-16 \mu \mathrm{g} / \mathrm{mL})$.

hRSV infection at MOI 0.5 induced syncytium formation and cellular death (Figure 3 ). The syncytium count was reduced when the cells were post-treated with NETs, particularly at higher concentrations ( 8 and $16 \mu \mathrm{g} / \mathrm{mL}$; Figure $3 \mathrm{~A}$, left). We also analyzed the area of the syncytia (Figure 3A, center), which remained at similar levels to that of the control at NET concentrations of $0.5-2 \mu \mathrm{g} / \mathrm{mL}$, but was reduced at higher NET concentrations $(4-16 \mu \mathrm{g} / \mathrm{mL})$. Morphological data confirmed the presence of syncytia and the cells were distant from each other (Figure 3B, top panel). Cells post-treated with NETs showed a similar morphology to infected control cells, including a reduction in the number of attached cells. The data showed that NETs did not provide a protective effect at concentrations of $0.5-2 \mu \mathrm{g} / \mathrm{mL}$ (Figure $3 \mathrm{~A}$, right). There was a trend toward improved results for treatment with NET concentrations of $4-16 \mu \mathrm{g} / \mathrm{mL}$, although this was not statistically significant $(\mathrm{p}>0.05)$. The presence of cells dying was confirmed through the trypan blue assays (Figure 3B, bottom panel). All infected cells, even those that were treated with NETs, showed large blue-colored regions, indicating cellular death.
Hep-2 cells were also post-treated with NETs after being infected with a higher viral inoculum (MOI 1.0) (Figure 4). All NET concentrations tested resulted in a reduction in the syncytium count in the infected cells (Figure 4A, left). On the other hand, NET concentrations of $0.5-4 \mu \mathrm{g} / \mathrm{mL}$ induced an increase in the area of the syncytia, while the cells treated with NETs at 8 and $16 \mu \mathrm{g} / \mathrm{mL}$ showed a reduced syncytium area (Figure $4 \mathrm{~A}$, center). These morphological changes can be seen in the images captured from the cell monolayer (Figure 4B, top panel). The CC showed cellular confluency. The presence of syncytia gradually decreased with increasing NET concentrations. It is important to note that there was a reduced number of attached cells after treatment with NETs at concentrations of $8-16 \mu \mathrm{g} / \mathrm{mL}$. Cellular viability results did not improve with NET treatment (Figure 4A, right). Trypan blue was incorporated in both treated and non-treated infected cells (Figure 4B, bottom panel), indicating cell damage. The lowest number of attached cells was observed in the wells treated with $16 \mu \mathrm{g} / \mathrm{mL}$ NETs. Our data demonstrate that the post-infection contact of hRSV-infected cells with NETs does not protect them from cellular damage.

\section{Discussion}

In hRSV-infected lung tissue, leukocyte recruitment occurs after the pathogens arrive in the tissue. Neutrophils 
A Syncytium count

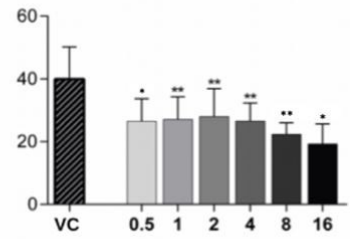

NET concentration $(\mu \mathrm{g} / \mathrm{mL})$
Syncytium size $\left(\mathrm{mm}^{2}\right)$

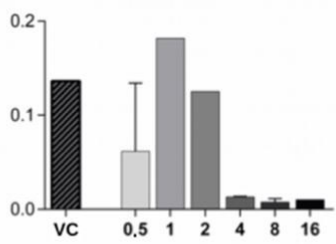

NET concentration $(\mu \mathrm{g} / \mathrm{mL})$

\section{Cellular viability $(\%)$}

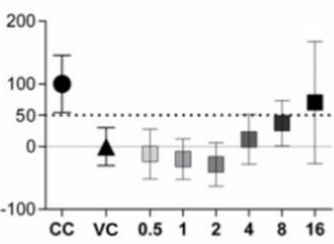

NET concentration $(\mu \mathrm{g} / \mathrm{mL})$

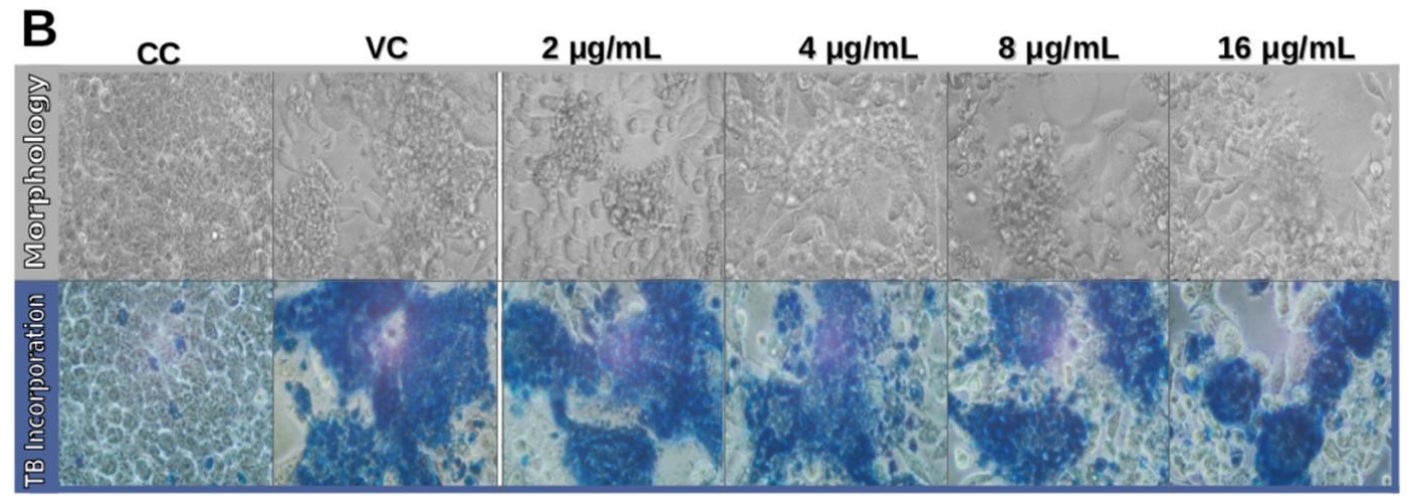

Figure 3. Effects of post-treatment with NETs on hRSV-infected cells (MOI 0.5). Hep-2 cells were infected with hRSV (MOI 0.5) and subsequently cultured in the presence of different NET concentrations $(0.5-16 \mu \mathrm{g} / \mathrm{mL})$. On the third day of culture, cells were evaluated for (A) syncytium number and area and cellular viability via the MTT assay, and (B) cell morphology and viability through trypan blue incorporation (TB incorporation). Graphs and images are representative of three independent experiments performed in triplicate. They show the mean of obtained values \pm standard deviation. $\left({ }^{*} \mathrm{p}<0.001,{ }^{* *} \mathrm{p}<0.0005\right.$ compared to the viral control, VC). Human respiratory syncytial virus (hRSV); neutrophil extracellular traps (NETs)

\section{A Syncytium count}

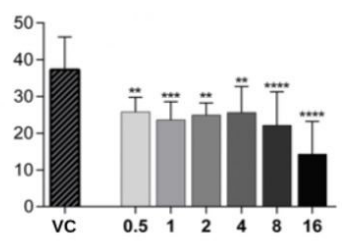

NET concentration $(\mu \mathrm{g} / \mathrm{mL})$
Syncytium size $\left(\mathrm{mm}^{2}\right)$

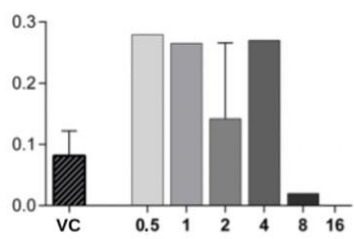

NET concentration $(\mu \mathrm{g} / \mathrm{mL})$

\section{Cellular viabiliy (\%)}

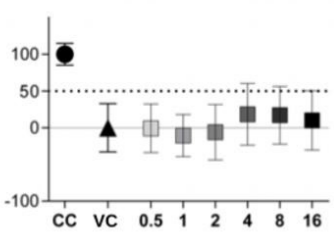

NET concentration $(\mu \mathrm{g} / \mathrm{mL})$

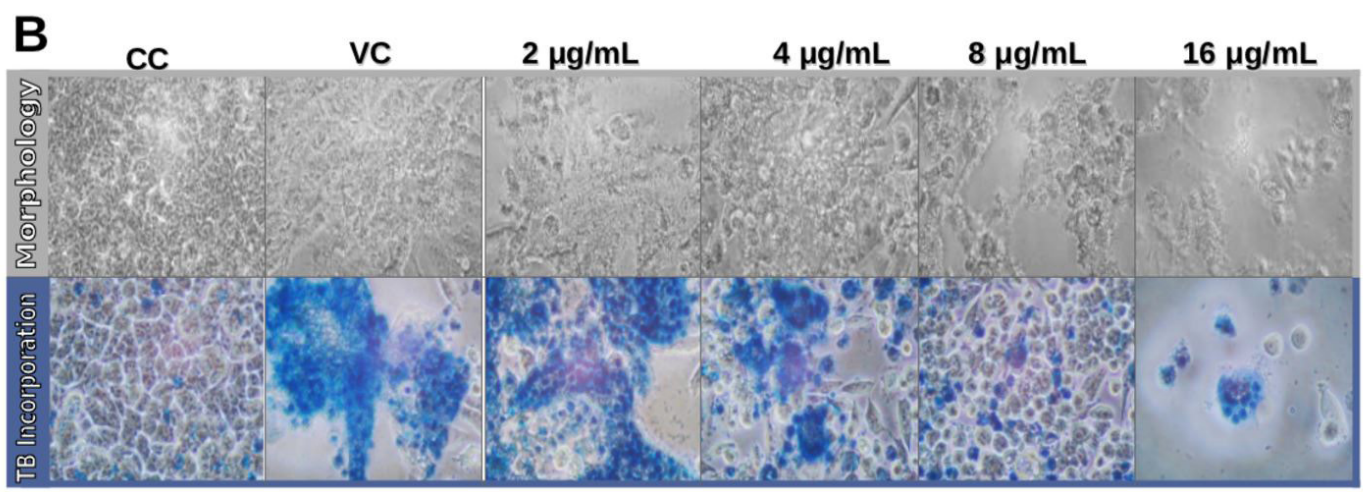

Figure 4. Effects of post-treatment with NETs on hRSV-infected cells (MOI 1.0). Hep-2 cells were infected with hRSV (MOI 1.0) and subsequently cultured in the presence of different NET concentrations $(0.5-16 \mu \mathrm{g} / \mathrm{mL})$. On the third day of culture, cells were evaluated for (A) syncytium number and area and cellular viability via the MTT assay, and (B) cell morphology and viability through trypan blue incorporation (TB incorporation). Graphs and images are representative of three independent experiments performed in triplicate. They show the mean of obtained values \pm standard deviation. $\left({ }^{* *} \mathrm{p}<0.01,{ }^{* * *} \mathrm{p}<0.001,{ }^{* * * *} \mathrm{p}<0.0001\right.$ compared to viral control, VC). Human respiratory syncytial virus (hRSV); neutrophil extracellular traps (NETs) 
are attracted by inflammatory mediators secreted by infected cells and other resident leukocytes (Nuriev and Johansson, 2019). Once they arrive at the site of infection, they are exposed to an environment with infected and non-infected cells, as well as extracellular viral particles.

Neutrophil accumulation in the respiratory tract tissues of patients infected with hRSV is well-documented (Smith et al., 2001; Everard et al., 1994). The contact between neutrophils and hRSV leads to several inflammatory responses, including the release of NETs via Toll-like receptors (TLRs) (Funchal et al., 2015). Although NETs have a microbicidal effect, their presence in tissues has also been reported to be associated with deleterious effects in various infections (Massberg et al., 2010; Narasaraju et al., 2011; Papayannopoulos et al., 2011). Thus, we aimed to investigate the role of NETs during hRSV infections in both infected and non-infected cells, using pre- and post-treatment protocols.

The NETs generated in this study were stimulated by PMA in the absence of FBS, since the latter contains DNAse that could break down traps (Zimmer et al., 2001). We analyzed the role of NETs during hRSV infection using two different protocols, pre- and post-treatment, in which cells were treated with NETs before or after a viral infection, respectively. In both treatments, NETs did not provide any protective effects. In the pre-treatment trials, there was reduction in the number and area of syncytia, but the rate of cell death was maintained. Post-treatment trials, in which Hep-2 cells were first infected and then underwent cultivation with NETs, showed a general trend of NETs aggravating the course of infection, mainly when they were treated with a viral inoculum of MOI 1.0.

Both pre- and post-treatments with NETs interfered with the number and size of syncytia in cells infected with hRSV. The term "respiratory syncytial virus" is based on the fact that infections generate syncytia as a result of the fusion of infected cells, leading to the formation of multinucleated cells. Studies indicate that a syncytium promotes an efficient and rapid viral cell-cell dissemination mechanism (Dutch et al., 2000; Pastey et al., 2000). We have not found any previous work that reported the interference of NETs with the size and number of syncytia, but it is known that the F-protein is a central mediator for the optimal induction of syncytia formation among viral proteins (Techaarpornkul et al., 2001). Although there is no correlation between the relative quantity of F-protein mRNA and the number or size of the syncytia (Gagliardi et al., 2017), it is interesting to note that there are some correlations between NETs and F-protein. F-protein stimulates neutrophils to produce NETs (Funchal et al., 2015), and in silico assays suggests that NETs can interact with F-protein (Souza et al., 2018). Future studies may answer whether the reduction in the number and size of syncytia induced by cellular treatment with NETs interferes with viral dissemination in tissue.

Kotelkin et al. (2003) demonstrated that hRSV infections sensitize cells to apoptotic cell death by modulating the expression of caspases and pro-apoptotic factors of the Bcl-2 family, as well as anti-apoptotic factors, such as Mcl-1. Saffarzadeh et al. (2012) observed cell death after in vitro incubation of endothelial and epithelial cells with NETs. The authors described that the cytotoxic effects of NETs were mediated by histones and myeloperoxidase. Souza et al. (2018) reported the antiviral effects of NET, where virus particles trapped by NETs were not able to infected and to kill the cells. Complementary, we demonstrated that the previous or posterior contact of cells with NETs did not protect against death induced by free virus particules. We conclude that NETs have a beneficial effect in capturing and reducing the number of infected cells, but they do not interfere with the cytopathic effect induced by the free viral particles that were able to infect the tissue."

In vivo strategies to inhibit or degrade NETs have yielded positive results (Caudrillier et al., 2012; Rossaint et al., 2014; Thomas et al., 2012). In these studies, DNAse or histone-blocking antibodies were used to reduce lung endothelial injury and protect mice from acute lung injury.

Here, we demonstrated that the contact of NETs with cells in two different stages of in vitro hRSV infection interferes with the number and size of syncytia while maintaining a constant rate of cell death. Our results reinforce the delicate and balanced action of NETs during hRSV infection when viral dissemination mechanisms, as syncytia, can be reduced in the presence of NETs, but the damage tissue is maintained in parallel. These aspects are important, and they need to be considered when designing new and specific pharmacological strategies against hRSV infection.

\section{Acknowledgements}

We thank the Coordenação de Aperfeiçoamento de Pessoal de Nível Superior (CAPES; Master's scholarship) and Fundação de Amparo à Pesquisa do Estado de São Paulo (FAPESP; Grant 2016/13867-3) for funding this study and the UNESP for institutional support.

\section{References}

BAWAGE, S.S., TIWARI, P.M., PILLAI, S., DENNIS, V. and SINGH, S.R., 2013. Recent advances in diagnosis, prevention, and treatment of human respiratory syncytial virus. Advances in Virology, vol. 2013, pp. 595768. http://dx.doi.org/10.1155/2013/595768. PMid:24382964.

BETTEGA, J.M., TEIXEIRA, H., BASSANI, V.L., BARARDI, C.R. and SIMÕES, C.M., 2004. Evaluation of the antiherpetic activity of standardized extracts of Achyrocline satureioides. Phytotherapy Research, vol. 18, no. 10, pp. 819-823. http://dx.doi.org/10.1002/ ptr.1568. PMid:15551398.

BRINKMANN, V., LAUBE, B., ABED, U.A., GOOSMANN, C. and ZYCHLINSKY, A., 2010. Neutrophil extracellular traps: how to generate and visualize them. Journal of Visualized Experiments, no. 36, pp. 1-3. http://dx.doi.org/10.3791/1724. PMid:20182410.

BRINKMANN, V., REICHARD, U., GOOSMANN, C., FAULER, B., UHLEMANN, Y., WEISS, D.S., WEINRAUCH, Y. and ZYCHLINSKY, A., 2004. Neutrophil extracellular traps kill bacteria. Science, vol. 303, no. 5663, pp. 1532-1535. http://dx.doi.org/10.1126/ science.1092385. PMid:15001782.

CAUDRILLIER, A., KESSENBROCK, K., GILLISS, B.M., NGUYEN, J.X., MARQUES, M.B., MONESTIER, M., TOY, P., WERB, Z. and LOONEY, M.R., 2012. Platelets induce neutrophil extracellular traps in 
transfusion-related acute lung injury. The Journal of Clinical Investigation, vol. 122, no. 7, pp. 2661-2671. http://dx.doi. org/10.1172/JCI61303. PMid:22684106.

CORTJENS, B., BOER, O.J., JONG, R., ANTONIS, A.F., PIÑEROS, Y.S.S., LUTTER, R., VAN WOENSEL, J.B. and BEM, R.A., 2016. Neutrophil extracellular traps cause airway obstruction during respiratory syncytial virus disease. The Journal of Pathology, vol. 238, no. 3, pp. 401-411. http://dx.doi.org/10.1002/path.4660. PMid:26468056.

DUBOIS, A.V., GAUTHIER, A., BRÉA, D., VARAIGNE, F., DIOT, P., GAUTHIER, F. and ATTUCCI, S., 2012. Influence of DNA on the activities and inhibition of neutrophil serine proteases in cystic fibrosis sputum. American Journal of Respiratory Cell and Molecular Biology, vol. 47, no. 1, pp. 80-86. http://dx.doi. org/10.1165/rcmb.2011-03800C. PMid:22343221.

DUTCH, R.E., JARDETZKY, T.S. and LAMB, R.A., 2000. Virus membrane fusion proteins: biological machines that undergo a metamorphosis. Bioscience Reports, vol. 20, no. 6, pp. 597-612. http://dx.doi.org/10.1023/A:1010467106305. PMid:11426696.

EVERARD, M.L., SWARBRICK, A., WRIGHTHAM, M., MCINTYRE, J., DUNKLEY, C., JAMES, P.D., SEWELL, H.F. and MILNER, A.D., 1994. Analysis of cells obtained by bronchial lavage of infants with respiratory syncytial virus infection. Archives of Disease in Childhood, vol. 71, no. 5, pp. 428-432. http://dx.doi.org/10.1136/ adc.71.5.428. PMid:7826113.

FUCHS, T.A., ABED, U., GOOSMANN, C., HURWITZ, R., SCHULZE, I., WAHN, V., WEINRAUCH, Y., BRINKMANN, V. and ZYCHLINSKY, A., 2007. Novel cell death program leads to neutrophil extracellular traps. The Journal of Cell Biology, vol. 176, no. 2, pp. 231-241. http://dx.doi.org/10.1083/jcb.200606027. PMid:17210947.

FUNCHAL, G.A., JAEGER, N., CZEPIELEWSKI, R.S., MACHADO, M.S., MURARO, S.P., STEIN, R.T., BONORINO, C.B.C. and PORTO, B.N., 2015. Respiratory syncytial virus fusion protein promotes TLR-4-dependent neutrophil extracellular trap formation by human neutrophils. PLoS One, vol. 10, no. 4, pp. e0124082. http:// dx.doi.org/10.1371/journal.pone.0124082. PMid:25856628.

GAGLIARDI, T.B., CRIADO, M.F., PROENÇA-MÓDENA, J.L., SARANZO, A.M., IWAMOTO, M.A., PAULA, F.E., CARDOSO, R.C., DELCARO, L.S., SILVA, M.L., CÂMARA, A.A. and ARRUDA, E., 2017. Syncytia induction by clinical isolates of human respiratory syncytial virus A. Intervirology, vol. 60, no. 1-2, pp. 56-60. http://dx.doi. org/10.1159/000480014. PMid:28869960.

GUPTA, C.K., LESZCZYNSKI, J., GUPTA, R.K. and SIBER, G.R., 1996. Stabilization of respiratory syncytial virus (RSV) against thermal inactivation and freeze-thaw cycles for development and control of RSV vaccines and immune globulin. Vaccine, vol. 14, no. 15, pp. 1417-1420. http://dx.doi.org/10.1016/S0264410X(96)00096-5. PMid:8994316.

HALL, C.B., 2001. Respiratory syncytial virus and parainfluenza virus. The New England Journal of Medicine, vol. 344, no. 25, pp. 1917-1928. http://dx.doi.org/10.1056/NEJM200106213442507. PMid: 11419430.

JENNE, C.N., WONG, C.H.Y., ZEMP, F.J., MCDONALD, B., RAHMAN, M.M., FORSYTH, P.A., MCFADDEN, G. and KUBES, P., 2013. Neutrophils recruited to sites of infection protect from virus challenge by releasing neutrophil extracellular traps. Cell Host $\mathcal{E}$ Microbe, vol. 13, no. 2, pp. 169-180. http://dx.doi.org/10.1016/j. chom.2013.01.005. PMid:23414757.

KOTELKIN, A., PRIKHOD'KO, E.A., COHEN, J.I., COLLINS, P.L. and BUKREYEV, A., 2003. Respiratory syncytial virus infection sensitizes cells to apoptosis mediated by tumor necrosis factorrelated apoptosis-inducing ligand. Journal of Virology, vol. 77, no. 17, pp. 9156-9172. http://dx.doi.org/10.1128/JVI.77.17.91569172.2003. PMid:12915532.
LARSEN, J.O., 1998. Stereology of nerve cross sections. Journal of Neuroscience Methods, vol. 85, no. 1, pp. 107-118. http://dx.doi. org/10.1016/S0165-0270(98)00129-0. PMid:9874147.

MANZENREITER, R., KIENBERGER, F., MARCOS, V., SCHILCHER, K., KRAUTGARTNER, W.D., OBERMAYER, A., HUML, M., STOIBER, W., HECTOR, A., GRIESE, M., HANNIG, M., STUDNICKA, M., VITKOV, L. and HARTL, D., 2012. Ultrastructural characterization of cystic fibrosis sputum using atomic force and scanning electron microscopy. Journal of Cystic Fibrosis: Official Journal of the European Cystic Fibrosis Society, vol. 11, no. 2, pp. 84-92. http://dx.doi.org/10.1016/j.jcf.2011.09.008. PMid:21996135.

MASSBERG, S., GRAHL, L., VON BRUEHL, M.-L., MANUKYAN, D., PFEILER, S., GOOSMANN, C., BRINKMANN, V., LORENZ, M., BIDZHEKOV, K., KHANDAGALE, A.B., KONRAD, I., KENNERKNECHT, E., REGES, K., HOLDENRIEDER, S., BRAUN, S., REINHARDT, C., SPANNAGL, M., PREISSNER, K.T. and ENGELMANN, B., 2010. Reciprocal coupling of coagulation and innate immunity via neutrophil serine proteases. Nature Medicine, vol. 16, no. 8, pp. 887-896. http://dx.doi.org/10.1038/nm.2184. PMid:20676107.

MATKOWSKYJ, K.A., SCHONFELD, D. and BENYA, R.V., 2000. Quantitative immunohistochemistry by measuring cumulative signal strength using commercially available software Photoshop and Matlab. The Journal of Histochemistry and Cytochemistry, vol. 48, no. 2, pp. 303-312. http://dx.doi. org/10.1177/002215540004800216. PMid:10639497.

MCKIMM-BRESCHKIN, J.L., 2004. A simplified plaque assay for respiratory syncytial virus - direct visualization of plaques without immunostaining. Journal of Virological Methods, vol. 120, no. 1, pp. 113-117. http://dx.doi.org/10.1016/j. jviromet.2004.02.020. PMid:15234816.

NAJMEH, S., COOLS-LARTIGUE, J., GIANNIAS, B., SPICER, J. and FERRI, L.E., 2015. Simplified human neutrophil extracellular traps (NETs) isolation and handling. Journal of Visualized Experiments, no. 98, pp. 353025. http://dx.doi.org/10.3791/52687. PMid:25938591.

NARASARAJU, T., YANG, E., SAMY, R.P., NG, H.H., POH, W.P., LIEW, A.A., PHOON, M.C., VAN ROOIJEN, N. and CHOW, V.T., 2011. Excessive neutrophils and neutrophil extracellular traps contribute to acute lung injury of influenza pneumonitis. American Journal of Pathology, vol. 179, no. 1, pp. 199-210. http://dx.doi.org/10.1016/j. ajpath.2011.03.013. PMid:21703402.

NURIEV, R. and JOHANSSON, C., 2019. Chemokine regulation of inflammation during respiratory syncytial virus infection. F1000Research, vol. 8, pp. 1837.

PAPAYANNOPOULOS, V., 2018. Neutrophil extracellular traps in immunity and disease. Nature Reviews. Immunology, vol. 18, no. 2, pp. 134-147. http://dx.doi.org/10.1038/nri.2017.105. PMid:28990587.

PAPAYANNOPOULOS, V., STAAB, D. and ZYCHLINSKY, A., 2011. Neutrophil elastase enhances sputum solubilization in cystic fibrosis patients receiving Dnase therapy. PLoS One, vol. 6, no. 12, pp. e28526. http://dx.doi.org/10.1371/journal.pone.0028526. PMid:22174830.

PASIEKA, T.J., WOOLSON, R.F. and GROSE, C., 2003. Viral induced fusion and syncytium formation: measurement by the Kolmogorov-Smirnov statistical test. Journal of Virological Methods, vol. 111, no. 2, pp. 157-161. http://dx.doi.org/10.1016/ S0166-0934(03)00152-6. PMid:12880931.

PASTEY, M.K., GOWER, T.L., SPEARMAN, P.W., CROWE JUNIOR, J.E. and GRAHAM, B.S., 2000. A RhoA-derived peptide inhibits syncytium formation induced by respiratory syncytial virus and parainfluenza virus type 3. Nature Medicine, vol. 6, no. 1, pp. 35-40. http://dx.doi.org/10.1038/71503. PMid:10613821. 
RASMUSSEN, L., MADDOX, C., MOORE, B.P., SEVERSON, W. and WHITE, E.L., 2011. A high-throughput screening strategy to overcome virus instability. Assay and Drug Development Technologies, vol. 9, no. 2, pp. 184-190. http://dx.doi.org/10.1089/ adt.2010.0298. PMid:21050067.

ROSSAINT, J., HERTER, J.M., VAN AKEN, H., NAPIREI, M., DÖRING, Y., WEBER, C., SOEHNLEIN, O. and ZARBOCK, A., 2014. Synchronized integrin engagement and chemokine activation is crucial in neutrophil extracellular trap-mediated sterile inflammation. Blood, vol. 123, no. 16, pp. 2573-2584. http://dx.doi.org/10.1182/ blood-2013-07-516484. PMid:24335230.

SAFFARZADEH, M., JUENEMANN, C., QUEISSER, M.A., LOCHNIT, G., BARRETO, G., GALUSKA, S.P., LOHMEYER, J. and PREISSNER, K.T., 2012. Neutrophil extracellular traps directly induce epithelial and endothelial cell death: a predominant role of histones. PLoS One, vol. 7, no. 2, pp. e32366. http://dx.doi.org/10.1371/ journal.pone.0032366. PMid:22389696.

SAITOH, T., KOMANO, J., SAITOH, Y., MISAWA, T., TAKAHAMA, M., KOZAKI, T., UEHATA, T., IWASAKI, H., OMORI, H., YAMAOKA, S., YAMAMOTO, N. and AKIRA, S., 2012. Neutrophil extracellular traps mediate a host defense response to human immunodeficiency virus-1. Cell Host $\&$ Microbe, vol. 12, no. 1, pp. 109-116. http://dx.doi.org/10.1016/j.chom.2012.05.015. PMid:22817992.

SMITH, P.K., WANG, S.Z., DOWLING, K.D. and FORSYTH, K.D., 2001 Leucocyte populations in respiratory syncytial virus-induced bronchiolitis. Journal of Paediatrics and Child Health, vol. 37, no. 2 , pp. 146-151. http://dx.doi.org/10.1046/j.1440-1754.2001.00618.x. PMid:11328469.

SOUZA, P.S.S., BARBOSA, L.V., DINIZ, L.F.A., SILVA, G.S., LOPES, B.R.P., SOUZA, P.M.R., ARAUJO, G.C., PESSOA, D., OLIVEIRA, J. SOUZA, F.P. and TOLEDO, K.A., 2018. Neutrophil extracellular traps possess anti-human respiratory syncytial virus activity: Possible interaction with the viral F protein. Virus Research, vol. 251, pp. 68-77.

STOKES, C.A., ISMAIL, S., DICK, E.P., BENNETT, J.A., JOHNSTON, S.L., EDWARDS, M.R., SABROE, I. and PARKER, L.C., 2011. Role of interleukin-1 and MyD88-dependent signaling in rhinovirus infection. Journal of Virology, vol. 85, no. 15, pp. 7912-7921. http://dx.doi.org/10.1128/JVI.02649-10. PMid:21593174.
STOKES, K.L., CURRIER, M.G., SAKAMOTO, K., LEE, S., COLLINS, P.L., PLEMPER, R.K. and MOORE, M.L., 2013. The respiratory syncytial virus fusion protein and neutrophils mediate the airway mucin response to pathogenic respiratory syncytial virus infection. Journal of Virology, vol. 87, no. 18, pp. 10070-10082. http:// dx.doi.org/10.1128/JVI.01347-13. PMid:23843644.

STOPPELENBURG, A.J., ROOCK, S., HENNUS, M.P., BONT, L. and BOES, M., 2014. Elevated Th17 response in infants undergoing respiratory viral infection. American Journal of Pathology, vol. 184, no. 5, pp. 1274-1279. http://dx.doi.org/10.1016/j. ajpath.2014.01.033. PMid:24650560.

TECHAARPORNKUL, S., BARRETTO, N. and PEEPLES, M.E., 2001. Functional analysis of recombinant respiratory syncytial virus deletion mutants lacking the small hydrophobic and/or attachment glycoprotein gene. Journal of Virology, vol. 75, no. 15, pp. 6825-6834. http://dx.doi.org/10.1128/JVI.75.15.68256834.2001. PMid:11435561.

THOMAS, G.M., CARBO, C., CURTIS, B.R., MARTINOD, K., MAZO, I.B., SCHATZBERG, D., CIFUNI, S.M., FUCHS, T.A., VON ANDRIAN, U.H., HARTWIG, J.H., ASTER, R.H. and WAGNER, D.D., 2012. Extracellular DNA traps are associated with the pathogenesis of TRALI in humans and mice. Blood, vol. 119, no. 26, pp. 6335-6343. http://dx.doi.org/10.1182/blood-2012-01-405183. PMid:22596262.

URBAN, C.F., ERMERT, D., SCHMID, M., ABU-ABED, U., GOOSMANN, C., NACKEN, W., BRINKMANN, V., JUNGBLUT, P.R. and ZYCHLINSKY, A., 2009. Neutrophil extracellular traps contain calprotectin, a cytosolic protein complex involved in host defense against Candida albicans. PLoS Pathogens, vol. 5, no. 10, pp. e1000639. http://dx.doi.org/10.1371/journal.ppat.1000639. PMid:19876394.

WRIGHT, T.K., GIBSON, P.G., SIMPSON, J.L., MCDONALD, V.M., WOOD, L.G. and BAINES, K.J., 2016. Neutrophil extracellular traps are associated with inflammation in chronic airway disease. Respirology, vol. 21, no. 3, pp. 467-475. http://dx.doi. org/10.1111/resp.12730. PMid:26804470.

ZIMMER, G., BUDZ, L. and HERRLER, G., 2001. Proteolytic activation of respiratory syncytial virus fusion protein. Cleavage at two furin consensus sequences. The Journal of Biological Chemistry, vol. 276, no. 34, pp. 31642-31650. http://dx.doi.org/10.1074/jbc. M102633200. PMid:11418598. 